\title{
Aktivitas Amilolitik Mikrofungi Endofit Serasah Daun dan Daun Mangrove Avicennia di Desa Sungai Bakau Kabupaten Mempawah
}

\author{
Warsidah $^{1 *}$, Mayang Sari Retno Marlangen ${ }^{1}$, Mega Sari Juane Sofiana ${ }^{1}$ \\ 1 Program studi Ilmu Kelautan, FMIPA, Universitas Tanjunpura, Pontianak- \\ Indonesia \\ *Correspondence email: Warsidah \\ $\nwarrow$ warsidah@fmipa.untan.ac.id
}

\author{
Received:26 September 2018- Accepted: 2 October 2018 \\ Published: 31 October 2018 @ Author(s) 2018. This article is open access
}

\begin{abstract}
Penelitian ini bertujuan untuk mendapatkan jenis mikrofungi endofit yang berpotensi memiliki aktivitas amilolitik dari serasah dan daun mangrove Avicennia. Mikrofungi endofit diisolasi pada media Potato Dextrose Agar diperoleh 42 isolat yang didominasi oleh isolat genus Aspergillus dan Penicillium. Skrining aktivitas amilolitik menggunakan media Glukosa, Yeast extract, Pepton, Starch Agar dan diuji dengan larutan iodin yang akan terbentuk zona bening pada media jika positif memiliki aktivitas amilolitik. Tujuh belas dari 42 isolat ditemukan memiliki aktivitas amilolitik. Kemampuan amilolitik yang paling besar didapat pada beberapa isolat berdasarkan zona beningnya, yaitu Fusarium ventrichosum, Aspergillus parasiticus, dan Oidiodendron cerealis.
\end{abstract}

Keywords: Amilolitik, mikrofungsi endofit, avicenmia

\section{Pendahuluan}

Mangrove menjadi ekosistem sumber daya alam di daerah tropis yang memiliki manfaat yang sangat luas (Bengen, 2004). Vegetasi mangove lebih berperan sebagai penyedia nutrisi melalui serasahnya terutama serasah yang berasal dari daun mangrove. Daun mangrove merupakan bagian terpenting dari produksi primer serasah. Daun mangrove Avicennia berperan sebagai tempat hidupnya berbagai jenis mikrofungi (Babu et al., 2012; Costa et al., 2012).

Mikrofungi endofit telah ditemukan hampir di semua bagian tumbuhan mangrove, seperti akar, ranting dan daun (Ananda, 2004). Mikrofungi endofit mempunyai fungsi bagi ekologi seperti meningkatkan pengambilan nutrien guna meningkatkan pertumbuhan tumbuhan ( $\mathrm{Li}$ et al., 2016). Penelitian yang telah dilakukan menunjukkan, bahwa mikrofungi endofit pada mangrove merupakan sumber penting penemuan senyawa bioaktif baru dan enzim ekstraselular (Ravindran et al., 2010; Monika et al., 2015; Ling et al., 2016).

Salah satu enzim ekstraselular yang banyak dihasilkan oleh mikroorganisme adalah enzim amilase. Enzim amilase adalah kelompok enzim hidrolitik yang dominan diproduksi dan diperdagangkan. Enzim ini memiliki peran penting dalam dunia industri, farmasi dan agrokimia seperti pembuatan sirup, kapsul obat, dan pembungkus pestisida (Sianturi, 2008; Sunitha et al., 2012). Penelitian yang telah dilakukan pada daun mangrove Avicennia di Hong Kong banyak 
ditemukan sumber isolat mikrofungi endofit yang mampu menghasilkan aktivitas amilolitik adalah Aspergillus sp., Penicillium sp., Colletotrichum sp., Fusarium sp., Mycelia sterelia, Phoma sp. dan Rhizopus sp. (Choi et al., 2005; Job et al., 2015). Daun serasah basah dan kering mangrove Avicennia di India banyak ditemukan sumber isolat mikrofungi endofit yang menghasilkan aktivitas amilolitik adalah Alternaria sp., Fusarium sp., Acremonium sp., Culvularia lunata, Glomerella sp. dan Cladosporium cladosporoides (Kumaresan, 2002).

\section{Metode}

\subsection{Waktu dan tempat}

Penelitian ini dilaksanakan pada bulan April sampai Agustus 2018. Pengambilan sampel serasah daun dan daun mangrove Avicennia dilakukan di Desa Sungai Bakau Kecil, Kabupaten Mempawah. Isolasi, identifikasi dan uji aktivitas amilolitik mikrofungi endofit serasah dan daun mangrove dilakukan di Laboratorium Riset dan Bioteknologi dan Laboratorium Mikrobiologi, Fakultas Matematika dan Ilmu Pengetahuan Alam, Universitas Tanjungpura.

\subsection{Pengambilan Sampel}

Sampel daun mangrove Avicennia yang diambil adalah dibedakan berdasarkan umurnya, yaitu daun serasah, daun tua, dan daun muda. Pengambilan daun muda dan tua dipetik langsung dari pohon mangrove Avicennia masing-masing sebanyak 5 helai daun dimasukkan dalam plastik sampel steril. Pengambilan serasah daun mangrove Avicennia dilakukan dengan menggunakan perangkap serasah yang terbuat dari net dengan mesh size 1,5 x $1,5 \mathrm{~mm}$ yang berukuran 100 x $100 \mathrm{~cm}$ (Sa'ban et al., 2013) yang diletakkan dibawah pohon mangrove. Perangkap serasah diletakkan selama 1 minggu.

\subsection{Analisis Data}

\subsubsection{Isolasi Mikrofungsi Endofit}

Serasah daun dan daun mangrove Avicennia masing-masing dicuci dengan akuades steril. Permukaan daun disterilisasi dengan memasukkannya ke dalam larutan etanol $70 \%$ selama 3 menit, kemudian dimasukkan ke dalam larutan $\mathrm{NaOCl} 4 \%$ selama 1 menit dan dikeringkan. Sampel selanjutnya dibilas dengan akuades steril. Daun yang telah bersih dipotong $1 \times 1 \mathrm{~cm}$, lalu diletakkan di atas cawan petri yang berisi media PDA dan disimpan pada suhu $28{ }^{\circ} \mathrm{C}$ selama 3-7 hari (Ling et al., 2016). Mikrofungi yang tumbuh diamati morfologi secara makroskopis, yaitu warna dan bentuk hifa (Adebola et al., 2015).

\subsubsection{Uji Aktivitas Amiliolitik}

Isolat mikrofungi endofit ditumbuhkan pada media agar GYP (Glukosa, Yeast Ekstrak, dan Pepton) dengan 0,2\% solube starch dan

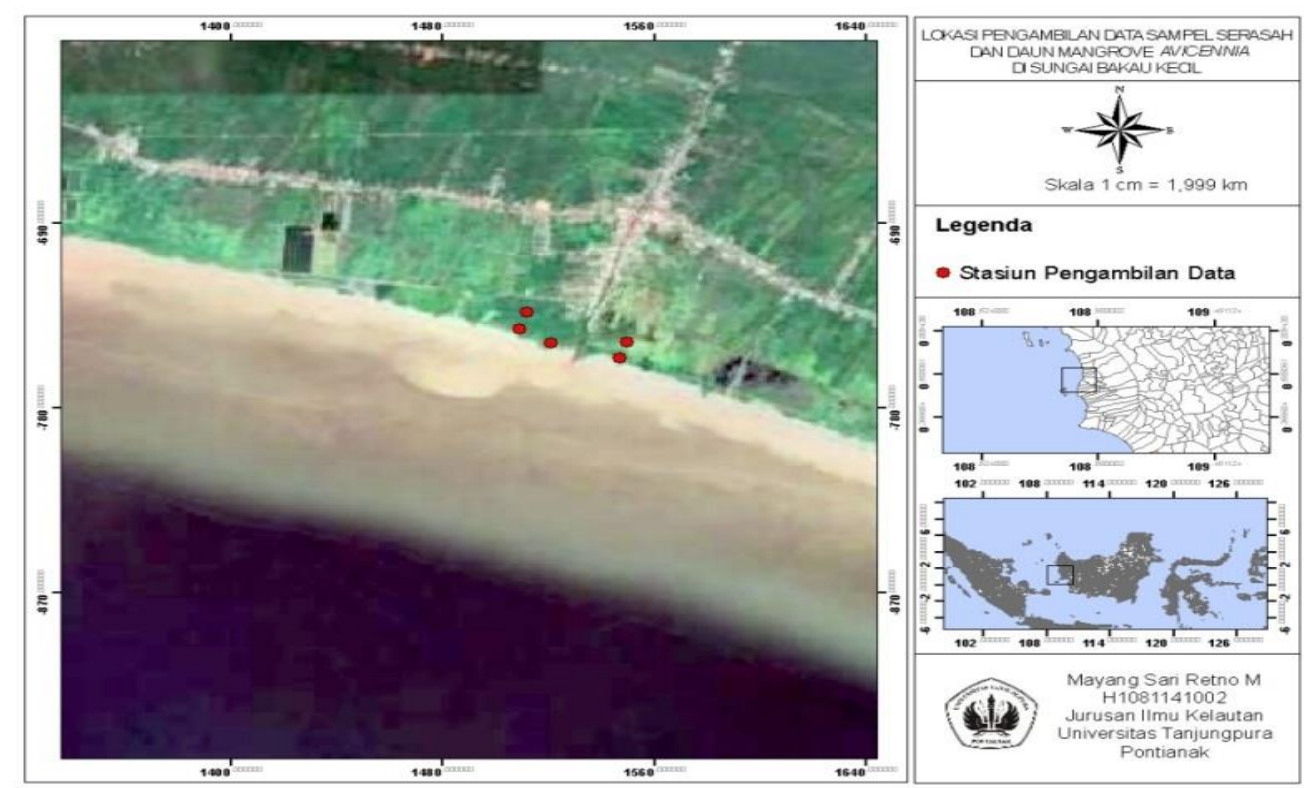

Gambar 1. Peta lokasi pengambilan sampel 
Tabel 1. Aktivitas amilolitik mikrofungi endofit serasah daun dan daun mangrove Avicennia

\begin{tabular}{|c|c|c|c|}
\hline No. & Spesies & Aktivitas Amilolitik & $\begin{array}{l}\text { Zona Bening } \\
(\mathrm{mm})\end{array}$ \\
\hline 1. & Gonatobotrys sp. & - & 0 \\
\hline 2. & Basipetospora rubra & - & 0 \\
\hline 3. & Plenodomus sp. & - & 0 \\
\hline 4. & Torula sp. & - & 0 \\
\hline 5. & $\begin{array}{l}\text { Mycocentrospora } \\
\text { acerina }\end{array}$ & - & 0 \\
\hline 6. & Chrysonilia sp. & - & 0 \\
\hline 7. & Dicyma pulvinata & - & 0 \\
\hline 8. & Fusarium ventrichosum & + & 8,1 \\
\hline 9. & Phialophora sp. & - & 0 \\
\hline 10. & Gliocladium roseum & - & 0 \\
\hline 11. & Aspergillus parasiticus & + & 1 \\
\hline 12. & Penicillium janthinellum & + & 0,8 \\
\hline 13. & $\begin{array}{l}\text { Taeniolella } \\
\text { phialosperma }\end{array}$ & - & 0 \\
\hline 14. & Oidiodendron flavum & - & 0 \\
\hline 15. & Acremonium sp. & + & 1,4 \\
\hline 16. & Mycelia sterelia & - & 0 \\
\hline 17. & Aspergillus clavati & + & 0,9 \\
\hline 18. & Culvularia prasadii & + & 1,5 \\
\hline 19. & Aspergillus parasiticus & + & 8,9 \\
\hline 20. & Sporotrichum sp. & - & 0 \\
\hline 21. & Mucor circinoides & + & 4,6 \\
\hline 22. & $\begin{array}{l}\text { Botryotrichum } \\
\text { piluliferum }\end{array}$ & - & 0 \\
\hline 23. & Chloridium virescens & - & 0 \\
\hline 24. & Phytophthora cryptogea & + & 1.2 \\
\hline 25. & Glioladium viride & - & 0 \\
\hline 26. & Rhizopus stolonizer & + & 1,7 \\
\hline 27. & Cylindrocladium citri & - & 0 \\
\hline 28. & Sclerotium sp. & - & 0 \\
\hline 29. & Aspergillus niger & + & 2,6 \\
\hline 30. & Oidiodendron cerealis & + & 7,2 \\
\hline 31. & Stachybotrys bisbyi & + & 0,7 \\
\hline 32. & Aspergillus niger & + & 0,8 \\
\hline 33. & Penicillium lanosum & + & 1,1 \\
\hline 34. & Mycelia sterelia & - & 0 \\
\hline 35. & Penicillium resticulosum & + & 2 \\
\hline 36. & Mycelia sterelia & + & 1,7 \\
\hline
\end{tabular}

+: positif; - : negatif

diinkubasi selama 4 hari. Isolat mikrofungi yang telah tumbuh, kemudian ditambahkan $1 \%$ iodin dan $2 \%$ potasium iodida. Aktivitas amilolitik ditandai dengan terbentuknya zona bening di sekitar isolat mikrofungi (Desire et al., 2014).

\subsubsection{Identifikasi Isolat Mikrofungsi Endofit}

Mikrofungi endofit pada daun serasah dan daun Avicennia diidentifikasi secara mikroskopis. Pengamatan ciri mikroskopis dengan melihat struktur hifa (bersekat atau tidak, hialin atau berwarna), bentuk struktur 
reproduksi aseksual (spora, konidia, dan konidiofor) (Ananda et al., 2004). Identifikasi mikrofungi hasil isolasi mengacu pada buku identifikasi Pictorial Altas of Soil and Seed Fungi Morphologis of Cultured Fungi and Key to Species (Watanabe, 2010).

\section{Hasil dan Pembahasan}

Hasil dari ketiga sampel daun mangrove Avicennia yang diisolasi, diperoleh koloni mikrofungi sebanyak 42 isolat yang terdiri dari 19 isolatpada serasahdaun (MS), 18 isolat pada daun tua (MT) dan 5 isolat pada daun muda (MM). Setelah dilakukan seleksi pada 42 isolat yang berpotensi menghasilkan aktivitas amilolitik hanya terpilih 17 isolat (Tabel 1).

Aktivitas amilolitik ditandai dengan terbentuknya zona bening di sekitar koloni mikrofungi yang tumbuh. Daerah di luar zona bening terlihat berwarna biru tua setelah ditetesi larutan iodin (Gambar 3). Warna biru tua terbentuk akibat adanya reaksi antara larutan iodin dengan pati yang tidak dihidrolisis. Zona bening tidak ikut terwarnai oleh larutan iodin karena pada zona tersebut amilum sudah terhidrolisis menjadi senyawa yang lebih sederhana seperti disakarida atau monosakarida. Koloni mikrofungi yang tumbuh dan ditetesi larutan iodin untuk mengetahui kemampuan mikrofungi dalam menghidrolisis amilum menjadi maltosa atau glukosa (Susilawati et al., 2015; Prahesti et al., 2018).

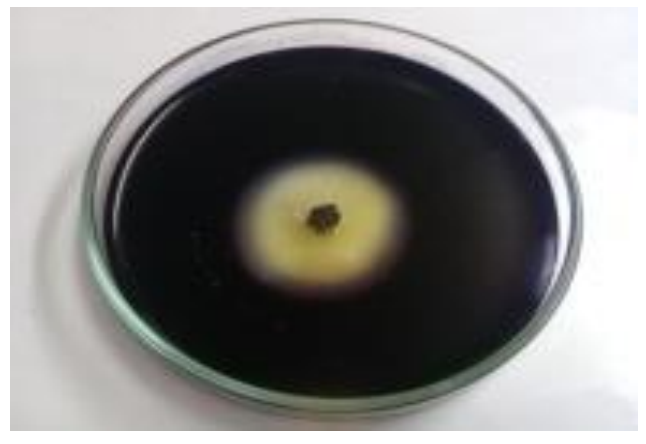

Gambar 2. Zona bening isolat MT03

Tujuh belas isolat dari 42 isolat mikrofungi endofit yang positif memiliki kemampuan amilolitik yang paling besar diperoleh 3 isolat berdasarkan zona beningnya, yaitu Fusarium ventrichosum, Aspergillus parasiticus, dan Oidiodendron cerealis. Ketiga jenis tersebut memiliki potensi yang paling besar dalam menghasilkan enzim amilase. seperti pada spesies Stachybotrys bisbyi memiliki kemampuan amilolitik yang paling kecil, sehingga pada jenis ini memiliki potensi yang rendah dalam menghasilkan enzim amilase. Hal ini sesuai dengan pernyataan Maria et al., (2005), bahwa potensi isolat penghasil enzim amilase dengan diameter zona bening yang semakin besar, maka memiliki potensi yang sangat bagus dalam menghasilkan enzim amilase.

Aktivitas amilolitik dihasilkan pada saat isolat mikrofungi berada pada fase eksponensial. Fase eksponensial terjadi pertumbuhan jumlah sel yang sangat banyak. Aktivitas sel pada fase ini sangat meningkat, sehingga mikrofungi akan menghasilkan banyaknya enzim yang di poduksi pada fase ini (Madavasamy et al., 2012; Ariandi, 2016). Aktivitas amilolitik akan menurun setelah sel mencapai fase eksponensial akhir, karena amilum dalam medium mulai habis, sehingga enzim tidak diproduksi lagi. Selain itu, akumulasi zat toksik di dalam mediumdapat menyebabkan penurunan aktivitas amilolitik (Susilawati et al., 2015).

\section{Kesimpulan}

Berdasarkan hasil penelitian yang telah dilakukan dapat diambil kesimpulan sebagai berikut:

1. Hasil dari isolasi sampel serasah daun dan daun mangrove Avicennia didapat 42 isolat murni yang terdiri dari 19 isolat dari daun serasah, 18 isolat dari daun tua dan 5 isolat dari daun muda.

2. Mikrofungi endofit yang menghasilkan aktivitas amilolitik didapat 17 isolat yaitu dari genus Aspergillus, Penicillium, Rhizopus, Mucor, Fusarium, Phytophthora, Culvularia, Oidiodendron, Stachybotrys, dan Acremonium. Genus yang paling dominan ditemukan pada Aspergillus, dan Penicillium.

\section{Ucapan Terima Kasih}

Penulis mengucapkan terimakasih kepada Kementerian Riset, Teknologi dan Pendidikan Tinggi Republik Indonesia atas program beasiswa Bidikmisi sehingga penulis dapat menyelesaikan riset di FMIPA UNTAN.

\section{Daftar Pustaka}

Adebola, A.L., Muid S., Mohamad H.B., Mansor W.Z., 2015, Microfungal Diversity on Leaves of Eusideroxylon zwageri, A Threatened Plant 
Species in Sarawak, Northern Borneo, J. Biodiversitas, 16:264-268.

Ananda, K., K.R. Sridhar, 2004, Diversity of Endophytic Fungi in the Roots of Mangrove Species on the West Coast of India, J. Microbiology, 48:871-878.

Ariandi, 2016, Pengenalan Enzim Amilase dan Rreaksi Enzimatisnya Menghidrolisis Amilosa Pati menjadi Glukosa, J. Dinamika, 7:74-82.

Babu, K.H., D. Ravi T., and K. Ramaneswari, 2012, Preliminary Observations on Microbial Diversity from Krishna Mangroves at Palakayatippa, Hamsaladevi in Andhra Pradesh on the East Coast of India, J. Pharm. Bio. Sci., 3:1181-1185.

Bengen, D.G, 2004, Ekosistem dan Sumberdaya Alam Pesisir dan Laut serta Prinsip Pengelolaannya, Pusat Kajian Sumberdaya Laut dan Pesisir Intitut Pertanian, Bogor.

Choi, Y.W., Hodggkiss, and K.D. Hyde, 2005, Enzyme Production by Endophytic of Brucea javanica, J. Agri. Tech., 4:55-66.

Costa, I.P.M.W., Leonor C.M., Maria A.C., 2012, Diversity of Leaf Endophytic Fungi in Mangrove Plants of Northeast Brazil, J. Microbiology, 107:1165-1173.

Desire, M.H., Fosto B., Muyang R.F., Chiatoh T.A., and Omokolo, 2014, Enzymes and Qualitative Phytochemical Screening of Endophytic Fungi Isolated from Lantana camara Lin. Leaves, J. Bio. Biotec., 2:001006.

Hughes, E., 2017, Endophytic Fungi Diversity, Characterization and Biocontrol, Nova Press, New York.

Job, N., Manomi S., Rosamma P., 2015, Isolation and Characterisation of Endophytic Fungi Avicennia officinalis, J. Bio. Biotech., 5:4-8.

Kumaresan, V., and T.S. Suryanarayanan, 2002, Endophyte Assemblages in Young, Mature, and Senescent Leaves of Rhizophora apiculata: Evidence for the Role of Endophyte in Mangrove Litter Degradation, J. Fungal Diversity, 9:81-91.

Li, J.L., Xiang S., Liang C., and Liang D. G., 2016, Community Structure of Endophytic Fungi of Four Mangrove Species in Southern China, J. Fungal Biology, 7:180-190.

Ling, O.M., Lim P.T., Azani M., Peter P., and Moritz M., 2016, Initial Screening of Mangrove Endophytic Fungi for Antimicrobial Compounds and Heavy Metal Biosorption Potential, J. Sains, 45:1063-1071.

Maria, G.L., K.R. Sridhhar, 2005, Antimicrobial and Enzyme Activity of Mangrove Endophytic Fungi of Southwest Coast of India, J. Agri. Tech., 4:67-80.

Monika, O.J., Anna J.W., Jolanta J.S., Katarzyna S., Artur R., Magdalena J., Ewa O., dan Malgorzata M., 2015, Extracellular Polysaccharides from Ascomycota and Basidiomycota: Production Conditions,
Biochemical Characteristics, and Biological Properties, J. Micro. Bio, 31:1823-1844.

Prahesti, D.A., Sri P., dan MG iswono R., 2018, Isolasi, Uji Aktivitas, dan Optimasi Inhibitor Amilase Isolat Kapang Endofit Tanaman Binahong, J. Biologi, 7:43-51.

Ravindran, C., T. Naveenan and G.R. Varatharajan, 2010, Optimization of Alkaline Celulase Production by the Marine Derived Fungus Chaetomium sp. Using Agricultural and Industrial Wastes as Substrates. J.Botanica Marine,53:275-28.

Sa'ban., Muh. Ramli., dan Wa Nurgaya, 2013, Produksi dan Laju Dekomposisi Serasah Mangrove dengan Kelimpahan Plankton di Perairan Mangrove Teluk Moramo, J. Mina Laut Indonesia, 3: 132-146.

Sunitha, V.H., Ramesha A., Savitha J., and Srinivas C., 2012, Amylase Production by Endophytic Fungi Cylindrocephalum sp. Isolated from Medicinal Plant Alpinia Calcarata (HAW) Roscoe, J. Microbiology, 105:1213-1221.

Sunitha, V.H., D. Nirmala, C. Srinivas, 2013, Extracellular Enzymatic Activity of Endophytic Fungal Strains Isolated from Medicinal Plants, J. Sciences, 9:01-09.

Susilawati, I.O., Ummi M.B., dan Hesti R., 2015, Analisis Akivitas Amilase yang Berasal dari Bakteri Tanah di Kawasan Universitas Jambi, J. Sains, Tek., 4:359-367.

Watanabe, T., 2010, Pictorial Atlas of Soil and Seed Fungi Morphologies of Cultured Fungi and Key to Species, Third Edition, CRC Press, New York. 